\title{
A Lady with Systemic Lupus Erythematosus and Mitral Stenosis
}

\author{
Muhammad Badrul Alam¹, Sania Hoque ${ }^{2}$, Amiruzzaman Khan ${ }^{3}$, Md. Zakir Hossain, Khondoker Asaduzzaman ${ }^{5}$
}

\begin{abstract}
:
Mitral stenosisis a valvular heart disease caused by a number of diseases. Chronic rheumatic fever is the most important cause. Among rare causes, some rheumatoid diseases like SLE may involve cardiovascular system causing libman- sacks endocarditis,pericardial diseases and other valvular lesions mostly associated with positive
\end{abstract}

antiphospholipid and anticardiolipin antibody.Here, we presented a case of rheumatic mitral valvular heart disease having systemic lupus erythromatosus but negative antiphospholipid and anticardiolipin antibody.

Keywords: Rheumatic fever, Systemic lupus erythematosis, Mitral stesnosis

\section{Introduction:}

Rheumatic fever(ARF) is the most important cause of valvular heart diseases, ${ }^{1}$ but there are some rheumatoid diseases where heart valves are also involved. ${ }^{2-7}$ Systemic lupus erythematosus (SLE) is one of the chronic systemic autoimmune disease, associated with valvular heart diseases, Libman-Sacks lesions, serositis, pericardial disease, venous and arterial thrombosis. All these manifestations are mostly associated with antiphospholipid antibodies. ${ }^{3}$ In a study conducted on echocardiography of SLE patients, variable valvular diseases such as mitral stenosis,mitral valve thickening or vegetation, mitral valve prolapsed, mitral, aortic, and tricuspid regurgitation; were reported. ${ }^{8}$ Here we reported a known case of rheumatic MS with incidental findings of SLE with negative antiphospholipid and anticardiolipin antibody.

History: A young lady of 34 years, housewife, normotensive, nondiabetic, admitted into CCU of Mitford Hospital on $9^{\text {th }}$ November 2015 with history of shortness

1. Professor, Department of Cardiology, Sir Salimullah Medical College, Dhaka, Bangladesh.

2. Junior Consultant, Department of Cardiology, Jessore Medical College, Jessore.

3. Associate Professor, Department of Cardiology, Sir Salimullah Medical College, Dhaka, Bangladesh.

4. Assistant Professor, Department of Cardiology, Sir Salimullah Medical College, Dhaka, Bangladesh.

5. Assistant Professor, Department of Cardiology, Sir Salimullah Medical College, Dhaka, Bangladesh.

Address of Correspondence: Dr. Muhammad Badrul Alam, Professor \& Head, Department of Cardiology, Sir Salimullah Medical College

\& Mitford Hospital, Dhaka, Bangladesh.

E-mail: mbadrulalam1958@gmail.com of breath for 6 years, palpitation for 2 years, multiple joint pain\& oral ulcer, skin rashes on face, arm \&legs for 2 months(Fig:1). She gave history of marked weight loss but there was no history of fever, spontaeneous abortion, bleeding,venous thrombosis or convulsion. She had history suggestive of rheumatic fever 22 years back and repeated hospital admission without any improvement.
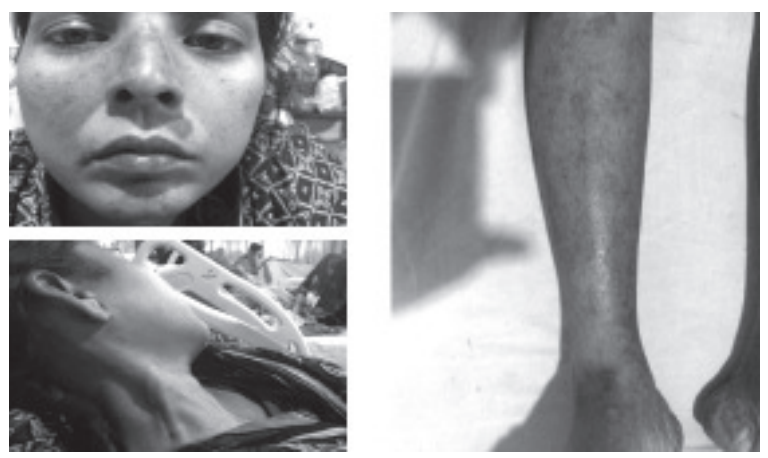

Fig-1: Characteristic rashes of SLE.

Clinical examination revealed tachycardia, dysponoea, anaemia, oedema, skin rashes over face, legs, arms, raised JVP, apex beat in left $5^{\text {th }}$ intercoastal space tapping in nature, palpable $P_{2}$, epigastric pulsation with left parasternal lift were present.There was loud first heart sound in mitral area with mid diastolic murmur and apansystolic murmur over left lower sternal edge. Liver was palpable and shifting dullness was present. Her both knees, ankles and small joints of both hands were swollen and tender.Investigations showed: $\mathrm{Hb} \%-9.8 \mathrm{gm} / \mathrm{dl}$, anti- 
nuclear Ab(ANA): positive, anti-ds DNA: positive, APL Ab: negetive, anti-cardiolipin-Ab: negetive, CCr-30.21 ml $/ \mathrm{min}$, ECG :sinus Tachycardia (Fig:2), pericardial effusion on XRay chest P/A view(Fig:3). Echocardiography revealed severe mitral stenosis (MVA-0.59cm2) with thicking and calcification of both $\mathrm{AML}$ and PML with diastolic doming of AMLwith fused both Commisures, moderate subvalvualar changes,moderate pericardial effusion $(23 \mathrm{~mm})$ with moderate pulmonary hypertension(PASP $-51 \mathrm{mmHg}$ ) without any thrombus (Fig:4).
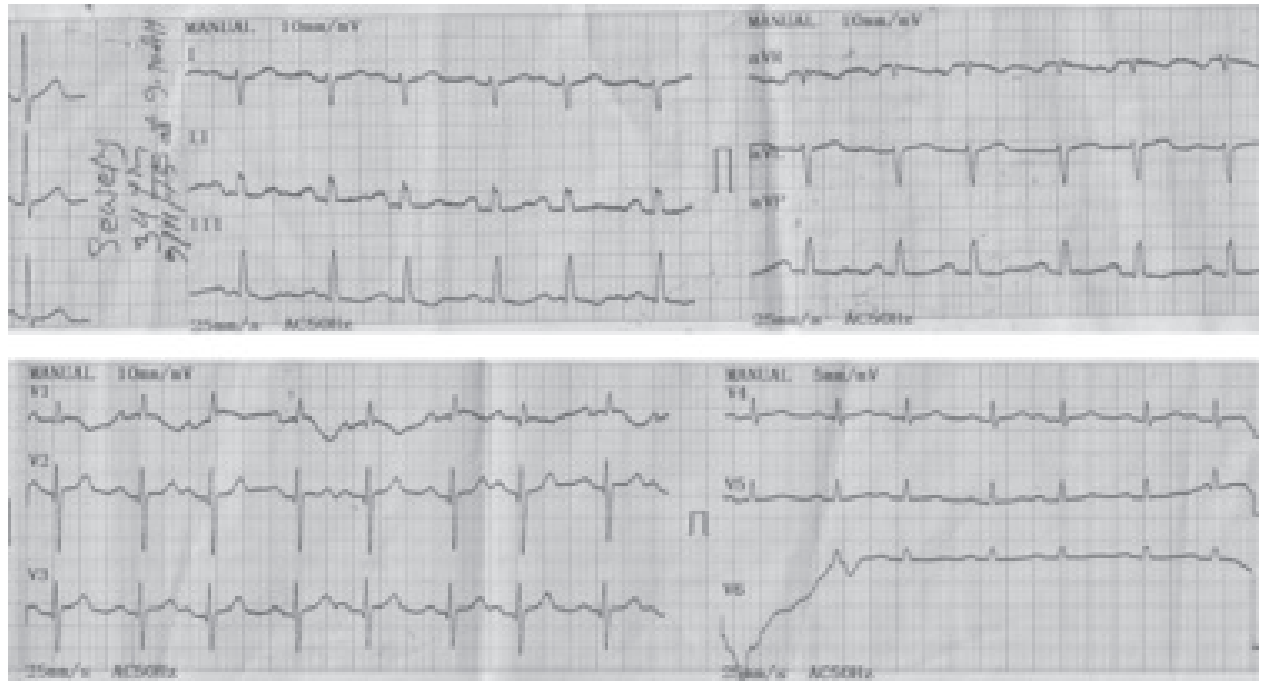

Fig.-2: ECG: Sinus tachycardia

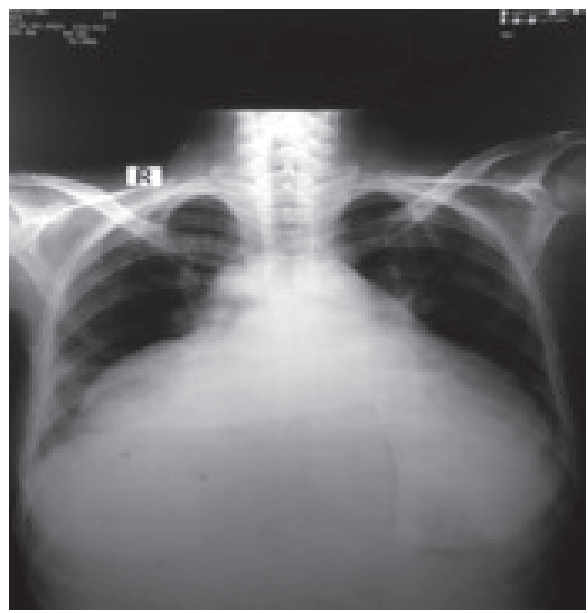

Fig-3: X-Ray chest P/A view: Features of pericardial effusion.
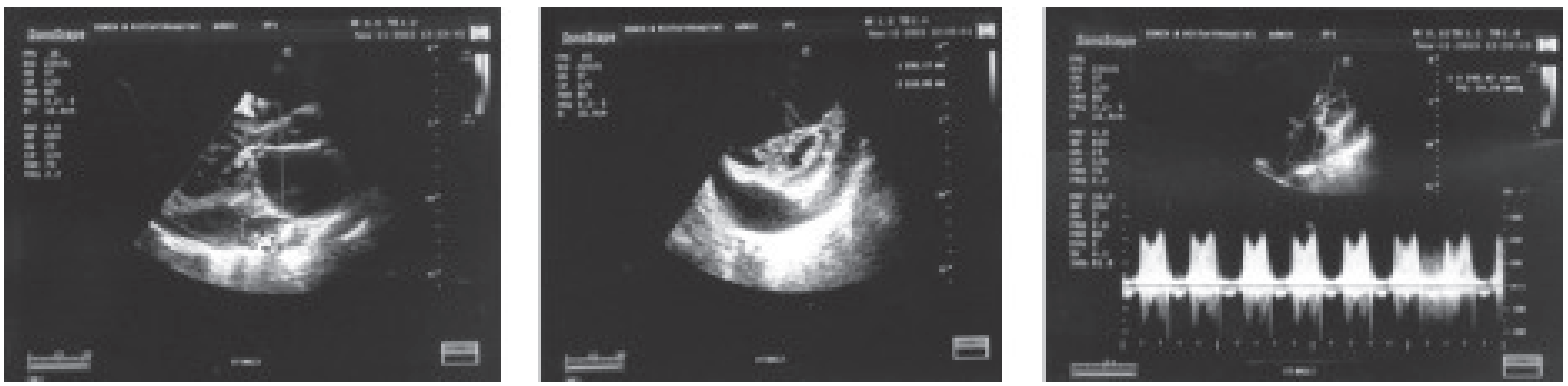

Fig-4: Echocardiography (2D,M-Mode and Doppler): Severe MS(MVA-0.59cm²), subvalvular changes and pericardial effusion . 
After diagnosis of SLE, hydroxychloroquine was added, subsequently patient developed visual impairment, fundoscopic examination found macular pigmentations.

\section{Discussion:}

Our patient was a known case of rheumatic valvular heart disease for last 22 years, as there was maculopapular skin rashes, investigations regarding SLE was done. SLE is an autoantibody and immune complex disorder, with immunoglobulin and complement deposition in involved organs, including the heart. The serologic findings may be detectable years before clinical disease manifests. ${ }^{9}$ In this patient valvular manifestations are mostly due to rheumatic fever because echocardiography showed mitral valve was severely stenosed (MVA-0.6cm2), both AML and PML were thickened and cacified with diastolic doming of AML, both commisures were fused, moderate subvalvualar changes without any thrombus,all these findings are in favour of chronic rheumatic heart disease, whereas in SLE echocradiographic findings include diffuse thickening of valve leaflets with minimal subvalvular changes.

Transthoracic and transesophageal echocardiography had shown that valvular involvement is greater in SLE patients who have positive antiphospholipid antibodies. ${ }^{10} \mathrm{~A}$ number of other manifestations may occur in SLE,most of which are associated with antiphospholipid and anticardiolipin antibodies, such as venous and arterial thrombosis, ${ }^{11}$ recurrent fetal loss, ${ }^{12}$ pulmonary hypertension, ${ }^{13}$ endocardial disease seizures, and migraine. ${ }^{14}$ But in our patient antiphospholipid and anticardiolipin antibody were negative.

Studies of patients with SLE have reported a $25 \%$ incidence of clinically evident pericarditis, a $50 \%$ incidence of pericardial effusion (detected by echocardiography), and $80 \%$ incidence of pericardial abnormalities at autopsy. ${ }^{15,16} \mathrm{Here}$, in our patient,we also found moderate pericardial effusion $(23 \mathrm{~mm})$ may be due pericarditis .

Over $95 \%$ of patients with SLE have a positive ANA; however, even high titers of ANA are not diagnostic of SLE. Anti-double-stranded DNA is more specific for SLE but is present in $50 \%$ to $70 \%$ of patients with idiopathic SLE, often in those with glomerulonephritis. Our case had strongly positive ANA and anti ds-DNA with impaired creatinine clearance $(30.21 \mathrm{ml} / \mathrm{min})$.

There are reports of mitral and aortic valve replacement in patients with SLE. ${ }^{17}$ Valve repair has also been described. ${ }^{18}$ Our further planning for management of this patient is mitral valve repair \&/or replacement.

We also found moderate pulmonary hypertension in this case, which is common in SLE ${ }^{19}$ but sig-nificant pulmonary hypertension is less common.

According to ACR/SLICC revised criteria for diagnosis of SLE,our patient had 9 points out of 16 (malar rash-2 points, oral ulcer-1 point,pericarditis-1 point,anemia-1 point, high titre ANA-2 points, positive anti ds-DNA-2 points ${ }^{20}$ and diagnosed a case of definite SLE.

The scope of investigations like renal biopsy,SPECT or endomyocardial biopsy were limited in this case, to find out further involvement of myocardium and kidney.

Our patient developed macular pigmentation on starting of hydroxychloroquine that need further evalution.

Conclusion: Anuncommon case of SLE without positive antiphospholipid and anticardiolipin antibody along with rheumatic origin of mitral stenosis is presented here. It is recommendeted that two different entity of mitral valvular disease can co-exist.

\section{References:}

1. Owlia M. B., Acute rheumatic fever, an acute or a chronic joint disease? Journal of Shahid Sadoughi University of Medical Sciences2011;19: 561-7.

2. Owlia M. B., Clinical spectrum of connective tissue disorders, Journal, Indian Academy of ClinicalMedicine 2006;7(3):217-24.

3. Roman M. J., Salmon J. E., "Cardiovascular manifestationsof rheumatologic diseases," Circulation 2007;116(20): 2346-55.

4. Kitas G., Banks M.J., and Bacon P.A., "Cardiac involvementin rheumatoid disease," Clinical Medicine 2001;1(1): 18-21.

5. Guedes C, Bianchi-Fior P, Cormier B, Barthelemy B, Rat A.C., and Boissier M.C., "Cardiac manifestations of rheumatoid arthritis: a casecontrol transesophageal echocardiographystudy in 30 patients, Arthritis Rheum 2001; 45(2): 129-35.

6. Turesson C, Jarenros J, and Jacobsson L, Increased incidenceof cardiovascular disease in patients with rheumatoid arthritis: results from a community based study, Ann Rheum Dis 2004; 63(8):952-5.

7. A. E. Voskuyl, "The heart and cardiovascular manifestationsin rheumatoid arthritis," Rheumatology 2006;45(4) iv4-iv7. 
8. Gabrielli F., E. Alcini, Di Prima MA, Mazzacurati G, and Masala $C$, "Cardiac valve involvement in systemic lupus erythematosus and primary antiphospholipid syndrome: lack of correlation with antiphospholipid antibodies," Int. J Cardiol; 51( 2):117-26.

16. Villa-Forte A and Mandel BF. Rheumatic Diseases and the Cardiovascular System. In Robert $O$ Bonoweditor.Braunwald"s Heart Disease: a text book of cardiovascular medicine. $10^{\text {th }}$ ed 2012;1885.

10. Harris EN, Gharavi AE, Boey ML, Mackworth-Young CG,Loizou S, Hughes GRV: Anticardiolipin antibodies: Detection with radioimmunoassay and association with thrombosis in SLE. Lancet 1983;2:1211-4.

11. Boey ML, Colaco CB, Gharavi AE, Elkon KB, LoizouS,Hughes GRV: Thrombosis in SLE: Striking association with the presence of circulating lupus anticoagulant. Br Med J 1983;287:1021-3

12. Sturfelt J, Nwed O, Norberg R, Thorstensson R, KrookK. Anticardiolipin antibodies in patients with systemic lupus erythematosus. Arthritis Rheum 1987;30:382-8

13. Asherson RA, Mackworth-Young CG, Boey ML, Hull RG,Saunders A, Gharavi AE. Pulmonary hypertension in SLE. Br Med J 1983;287:1024-5
14. Hughes GRV, Harris EN, Gharavi AE. The anticardiolipin syndrome. I Rheumatol 1986; 13:486-9

15. Chryer PE, Kissane JM: Mixed connective tissue disease. Am J Med 1978;65: 833.

16. Cooke CL, Lurie HI: Fatal gastrointestinal hemorrhage in mixed connective tissue disease. Arthritis Rheum 1977;20: 1421-1977.

17. Fluture A, Chaudhari S, Frishman WH. Valvular heart disease and systemic lupus erythematosus: Therapeutic Implications. Heart Dis 2003;5(5): 349-53.

18. Perez-Villa F, Font J, Azqueta M, Espinosa E, Pare C, Cervera R. et al: Severe valvular regurgitation and antiphospholipid antibodies in systemic lupus erythematosus: A prospective, long-term follow-up study. Arthritis Rheum 2005;53(3):460-7.

19. Johnson SR, Gladman DD, Urowitz MB, Obanez D, Granton JT. Pulmonary hypertension in systemic lupus. Lupus 2004;13(7):506-9.

20. Saleli - Abari I. ACR/Slice Revised Criteria for Diagnosis of Systemic Lupus Erythromatosus. Autoimmune Dis Ther Approaches 2015;2:114. 